\title{
Pengaruh Faktor Internal dan Eksternal Perusahaan Terhadap Praktik Manajemen Laba di Perusahaan Publik Sektor Barang Konsumsi Periode 2014-2018
}

\author{
Andreas Cahyadi ${ }^{*}$, Arthik Davianti $^{2}$ \\ 1,2, Fakultas Ekonomika dan Bisnis Akuntansi, Universitas Kristen Satya Wacana
}

\section{A R T I C L E I N F O}

Article history:

Received 15 February 2020

Received in revised form

30 March 2020

Accepted 20 April 2020

Available online 28 May 2020

\section{Kata Kunci:}

Manajemen Laba Real,

Komposisi Dewan

Komisaris Independen, CEO

tenure, Ukuran KAP,

Profitabilitas, Ukuran

Perusahaan.

Keywords:

Real Profit Management, Independent Board of

Commissioners

Composition, CEO tenure,

KAP Size, Profitability,

Company Size.

\begin{abstract}
A B S T R A K
Penelitian ini bertujuan untuk menguji pengaruh antara faktor internal dan eksternal perusahaan yang terdiri dari komposisi dewan komisaris independen, CEO tenure, dan ukuran KAP terhadap praktik manajemen laba real yang diukur menggunakan abnormal CFO. Penelitian ini juga menggunakan variabel kontrol yaitu profitabilitas dan ukuran perusahaan. Penelitian dilakukan pada perusahaan manufaktur sektor barang konsumsi yang terdaftar di Bursa Efek Indonesia periode 2014-2018. Data yang digunakan berupa data sekunder yang diperoleh dari laporan keuangan dan laporan tahunan perusahaan dan dianalisis menggunakan teknik uji regresi liner berganda. Sampel dipilih dengan menggunakan teknik purposive sampling dengan beberapa kriteria dan terpilih 48 perusahaan. Hasil penelitian ini menunjukkan bahwa CEO tenure dan ukuran KAP tidak berpengaruh terhadap manajemen laba, sedangkan komposisi dewan komisaris independen dan profitabilitas berpengaruh positif terhadap manajemen laba, dan ukuran perusahaan berpengaruh negatif terhadap manajemen laba
\end{abstract}

\section{A B S T R A C T}

This study aimed to examine the effect of internal and external factors consisting of the proportion of independent board commissioner, CEO tenure, the size of Public Accountant Firm (PAF) to the real earnings management which is measured by abnormal CFO. This study also uses control variables such as profitability and company size. The study has conducted on manufacturing companies in the consumer goods sector listed in Indonesian Stock Exchange from 2014-2018. The data in this research is secondary data which are taken from financial reports and annual reports, data were analyzed using multiple linear regression test. The sample was selected using a purposive sampling method with several criteria and 48 companies were selected as a sample. The result shows that CEO tenure and the size of Public Accountant Firm (PAF) do not have effect on the real earnings management, while the proportion of independent board commissioner and profitability have a positive effect on the real earnings management, and company size has a negative effect on the real earnings management.

\footnotetext{
* Corresponding author.

E-mail addresses: arthik.davianti@uksw.edu (Andreas Cahyadi, Arthik Davianti)
} 


\section{Pendahuluan}

Keberadaan Kinerja suatu perusahaan seringkali diukur dengan menggunakan laporan keuangan yang telah dihasilkan (Kristiani, Sulindawati, \& Herawati, 2014). Bagi perusahaan yang telah go public, laporan keuangan menjadi hal penting yang akan diperhatikan oleh investor dalam melakukan investasi disebuah perusahaan. Namun sayangnya, angka-angka dalam laporan keuangan perusahaan terutama di dalam laporan laba rugi tidak selalu menunjukkan keadaan perusahaan yang sebenarnya (Puspitasari \& Nugrahanti, 2016). Manajemen akan memainkan laba untuk tujuan yang ingin dicapai. Laba akan dibuat seolah-olah rendah dengan maksud untuk menghindari pembayaran pajak yang tinggi sedangkan laba akan dibuat tinggi untuk menunjukkan kinerja yang bagus dari perusahaan (Hanna \& Haryanto, 2016). Praktik seperti ini disebut juga dengan manajemen laba.

Berbagai fenomena terkait manajemen laba yang dilakukan oleh perusahaan telah banyak terjadi, Beberapa waktu yang lalu muncul sebuah kasus ketika sebuah perusahaan yang memproduksi makanan ringan "Taro" yang cukup terkenal di Indonesia, yaitu PT Tiga Pilar Sejahtera (AISA) terindikasi melakukan penggelembungan nilai pada akun-akun akuntansi seperti piutang, aset tetap, dan juga persediaan. Penggelembungan nilai ini berasal dari beberapa sumber diantaranya melalui transaksi terhadap pihak yang terafiliasi dan perbedaan data yang digunakan untuk pembukuan bagi pihak internal perusahaan dan yang digunakan untuk audit eksternal (Arief, 2019). Terdapat berbagai macam faktor yang dapat mempengaruhi keputusan manajemen ketika akan melakukan praktik manajemen laba (Susanto \& Majid, 2017). Faktor tersebut dapat berasal dari dalam maupun dari luar perusahaan. Dengan struktur perusahaan Indonesia yang menganut two-tier system, perusahaan akan memisahkan antara Board of Commissioners dan Board of Directors. Tindakan manajemen laba dapat dideteksi melalui kedua faktor internal tersebut.

Komposisi dewan komisaris merupakan gabungan pengawas perusahaan yang berasal dari dalam dan luar perusahaan atau yang disebut dengan komisaris independen. Dewan komisaris memiliki fungsi penting dalam jalannya sebuah perusahaan, dewan komisaris akan mengontrol segala keputusan atau kebijakan yang diambil oleh manajemen yang berimplikasi pada kualitas informasi yang akan disajikan. Fatmawati (2018) serta Nabila \& Daljono (2013) menyebutkan komposisi dewan komisaris independen yang ada pada perusahaan berpengaruh negatif terhadap manajemen laba hal ini disebabkan bahwa manajemen akan mengurangi atau bahkan tidak melakukan manajemen laba apabila terdapat banyak dewan komisaris independen yang melakukan pengawasan. Namun penelitian yang dilakukan oleh Marpaung \& Latrini (2014) dan Octavia (2017) menghasilkan kesimpulan yang berbeda yaitu komposisi dewan komisaris tidak berpengaruh terhadap praktik manajemen laba.

Ketidakpastian iklim bisnis serta kondisi ekonomi akan menyulitkan kinerja CEO dalam memenuhi tuntutan untuk membawa perusahaan selalu terlihat baik dimata investor maupun pemegang saham. Dalam situasi seperti inilah muncul perilaku oportunis dalam diri CEO untuk mempertahankan posisi sebagai CEO perusahaan (Yasa \& Novialy, 2012). Penelitian yang dilakukan oleh Adiasih \& Kusuma (2011), Vernando \& Rakhman (2018), dan Yasa \& Novialy (2012) berhasil membuktikan bahwa CEO hanya melakukan manajemen laba pada saat baru menjabat atau berada diawal masa jabatannya dengan cara menurunkan laba. Penelitian Dewi \& Rasmini (2018) menemukan hal yang berbeda yaitu baik CEO lama maupun baru akan melakukan manajemen laba.

Lebih lanjut, praktik manajemen laba juga dapat terdeteksi melalui faktor eksternal perusahaan seperti ukuran KAP. Ukuran KAP dilihat melalui auditor yang tercermin pada auditor Kantor Akuntan Publik yang digunakan oleh perusahaan, karena semakin besar ukuran KAP maka semakin mudah bagi KAP tersebut untuk menemukan praktik manajemen laba. Penelitian yang dilakukan oleh Inaam, Khmoussi, \& Fatma (2012) dan Puspitasari \& Nugrahanti (2016) menjelaskan ukuran KAP berpengaruh positif terhadap manajemen laba real, perusahaan lebih memilih untuk melakukan manajemen laba real guna menghindari deteksi dari auditor KAP yang bereputasi tinggi, berbeda dengan penelitian Nihlati \& Meiranto (2014) yang menyebutkan bahwa ukuran KAP berpengaruh negatif terhadap potensi manajemen laba real.

Setiap perusahaan dapat terpengaruh untuk melakukan manajemen laba, tak terkecuali dengan perusahaan besar yang sudah go public. Pengaruh tersebut tidak hanya berasal dari dalam perusahaan namun juga dapat berasal dari lingkungan di luar perusahaan. Dengan adanya rekayasa dalam penyajian laba melalui manajemen laba real akan mengakibatkan informasi yang diterima investor tidak valid. Berdasarkan persoalan penelitian tersebut dapat ditarik sebuah pertanyaan penelitian yaitu bagaimanakah faktor internal dan eksternal mempengaruhi perusahaan untuk melakukan manajemen laba?

Penelitian ini berfokus pada tingkat signifikansi masing-masing faktor yang mempengaruhi perusahaan dalam melakukan manajemen laba apakah terletak pada faktor internal perusahaan atau 
justru berasal dari faktor eksternal perusahaan dengan menggunaakan manajemen laba real. Penelitian ini bertujuan untuk memperoleh bukti empiris mengenai tingkat signifikansi antara hubungan faktor internal dan eksternal perusahaan terhadap praktik manajemen laba. Manfaat yang bisa didapatkan melalui penelitian ini adalah sebagai tambahan informasi bagi investor yang akan melakukan investasi terkait tindakan perusahaan dalam menyajikan laba, dan sebagai bahan referensi bagi penelitianpenelitian selanjutnya yang terkait dengan topik yang serupa.

\section{Metode}

Jenis Penelitian ini dirancang dengan menggunakan pendekatan kuantitatif dengan teknik analisis regresi linier berganda serta akan menggunakan data sekunder berupa laporan keuangan tahunan perusahaan yang di-publish ke dalam website Bursa Efek Indonesia (www.idx.co.id). Populasi yang digunakan dalam penelitian ini adalah perusahaan-perusahaan yang termasuk ke dalam golongan perusahaan sektor barang konsumsi pada periode 2014-2018. Sektor barang dan konsumsi dipilih karena sektor ini menjadi salah satu tumpuan bagi pertumbuhan industri manufaktur dan juga memberi kontribusi yang besar dalam menyumbang pertumbuhan ekonomi Indonesia. Perusahaan-perusahaan yang dijadikan sampel dipilih dengan menggunakan beberapa kriteria yang telah ditetapkan (purposive sampling).

Tabel 1. Populasi dan Sampel

\begin{tabular}{ll}
\hline Kriteria & Data \\
\hline Perusahaan yang bergerak pada sektor barang konsumsi terdaftar di Bursa & 53 \\
Efek Indonesia (BEI) pada tahun 2014, 2015, 2016, 2017 dan 2018. & \\
$\begin{array}{l}\text { Perusahaan yang tidak berturut-turut mempublikasikan laporan keuangan } \\
\text { tahunan di www.idx.co.id tahun 2014, 2015, 2016, 2017, dan 2018. }\end{array}$ & (5) \\
\hline \multicolumn{1}{c}{ Perusahaan yang menjadi sampel penelitian } & 48 \\
\hline
\end{tabular}

Berikut persamaan yang digunakan untuk mengukur manajemen laba real dengan menggunakan proksi abnormal CFO :

$\frac{C F O_{t}}{A_{t-1}}=\alpha_{0}+\alpha_{1}\left(\frac{1}{A_{t-1}}\right)+\alpha_{2}\left(\frac{S_{t}}{A_{t-1}}\right)+\alpha_{a}\left(\frac{\Delta S_{t}}{A_{t-1}}\right)+\varepsilon_{t}$

Keterangan :

$\mathrm{CFO}_{\mathrm{t}} \quad=$ arus kas operasi perusahaan pada tahun ke $\mathrm{t}$

$\mathrm{A}_{\mathrm{t}-1} \quad=$ total aset perusahaan pada tahun $\mathrm{t}-1$

$\mathrm{S}_{\mathrm{t}} \quad=$ total penjualan perusahaan selama tahun $\mathrm{t}$

$\varepsilon_{\mathrm{t}} \quad=$ residual regresi

Nilai dari abnormal CFO yang digunakan untuk melihat ada tidaknya manajemen laba real untuk setiap perusahaan yang diteliti akan ditunjukkan oleh komponen residual regresi dari persamaan diatas.

\section{Variabel Independen}

Variabel bebas yang akan diteliti dalam penelitian ini terdiri dari komposisi dewan komisaris, CEO tenure serta ukuran KAP.

1. Komposisi Dewan Komisaris

Variabel ini akan diukur dengan cara menghitung perbandingan persentase dewan komisaris independen dibagi dengan total keseluruhan anggota dewan komisaris yang ada dalam perusahaan (Nabila \& Daljono, 2013).

2. CEO Tenure

CEO tenure akan dibagi menjadi 2 kelompok variabel yaitu dilihat dari awal masa kerja dan akhir masa kerja. Variabel ini diukur dengan menggunakan variabel dummy, untuk variabel CEO awal yang berada di awal masa kerja akan diberi nilai 1 dan 0 untuk CEO yang mendekati akhir masa kerja, begitu pula dengan variabel CEO akhir yang berada di akhir masa kerja akan diberi nilai 1 dan 0 jika tidak (Muniroh, 2016).

3. Ukuran KAP 
Variabel dummy juga akan digunakan untuk mengukur variabel ukuran KAP. Nilai 1 akan diberikan apabila perusahaan menggunakan auditor dari KAP yang berafiliasi dengan KAP big four (Puspitasari \& Nugrahanti, 2016).

Variabel Kontrol

Penelitian ini menggunakan dua variabel kontrol yaitu profitabilitas dan ukuran perusahaan.

1. Profitabilitas

Profitabilitas dilihat dari rasio Return on Asset, yang menunjukkan keefektifan perusahaan dalam hal menciptakan laba melalui aset yang dimiliki.

2. Ukuran Perusahaan (Size)

Variabel ini akan diukur dengan menggunakan log dari total aset. Vernando \& Rakhman (2018) menyebutkan bahwa ukuran perusahaan memiliki hubungan negatif dengan manajemen laba, karena perusahaan yang berukuran besar akan cenderung lebih stabil dan berhati-hati dalam menyajikan laba.

Penelitian ini menggunakan model penelitian sebagai berikut :

$E M=a+D K+C E O$ Tenure + KAP + Profit + Size $+e$

\section{Hasil dan pembahasan}

Tabel 2. Statistik Deskriptif

\begin{tabular}{lccccc}
\hline $\begin{array}{c}\text { Variabel } \\
\text { Penelitian }\end{array}$ & $\mathrm{N}$ & Minimum & Maximum & Mean & Std. Deviation \\
\hline EM & 209 & $-0,563$ & 0,759 & $-0,00425$ & 0,1516 \\
DK & 209 & 0,00 & 0,80 & 0,38184 & 0,127 \\
CEO AWAL & 209 & 0,00 & 1,00 & - & 0,412 \\
CEO AKHIR & 209 & 0,00 & 1,00 & - & 0,405 \\
KAP & 209 & 0,00 & 1,00 & - & 0,488 \\
PROFIT & 209 & $-26,037 \%$ & $92,100 \%$ & $7,893 \%$ & $12,902 \%$ \\
SIZE & 209 & 25,332 & 32,201 & 28,409 & 1,564 \\
Valid N & 209 & & & & \\
\hline
\end{tabular}

Sumber: Data sekunder yang diolah tahun 2020.

\begin{tabular}{lccc}
\hline Variabel Dummy & & 0 & 1 \\
\hline CEO AWAL & 209 & $164(78,5 \%)$ & $45(21,5 \%)$ \\
CEO AKHIR & 209 & $166(79,4 \%)$ & $43(20,6 \%)$ \\
KAP & 209 & $128(61,2 \%)$ & $81(38,8 \%)$ \\
Valid N & 209 & & \\
\hline
\end{tabular}

Sumber: Data sekunder yang diolah tahun 2020.

Berdasarkan Tabel 2 di atas, variabel manajemen laba real yang dihitung dengan menggunakan persamaan abnormal CFO diperoleh nilai minumum sebesar -0,563 dan nilai maksimum 0,759 serta ratarata $-0,00425$. Sesuai dengan penelitian yang dilakukan oleh Braam et al., (2015) bahwa dengan rata-rata yang bernilai negatif maka dapat diindikasikan bahwa perusahaan sektor barang konsumsi yang dipilih menjadi sampel penelitian melakukan praktik manajemen laba real, melalui manipulasi penjualan yang berakibat pada arus kas operasi perusahaan.

Untuk variabel komposisi dewan komisaris independen (DK) memiliki nilai terendah 0 dan nilai maksimum 0,80 dengan nilai rata-rata sebesar 0,38263. Nilai 0 tersebut menunjukkan bahwa terdapat perusahaan yang tidak memiliki dewan komisaris independen sama sekali sedangkan 0,8 adalah nilai yang dimiliki oleh PT Unilever Indonesia Tbk yang menunjukkan bahwa dari keseluruhan anggota dewan komisaris perusahaan yang berjumlah lima orang, empat diantaranya merupakan dewan komisaris independen. Variabel CEO tenure terdiri atas CEO awal dan juga CEO akhir. Untuk variabel CEO awal yang berada diawal masa kerja hanya sebesar 45 perusahaan yaitu 21,5\%, sedangkan variabel CEO akhir yang berada diakhir masa kerja sebesar 43 perusahaan atau 20,6\%.

Berdasarkan Tabel 2 variabel ukuran kantor akuntan publik (KAP), dari 209 perusahaan sampel didominasi oleh perusahaan yang menggunakan KAP non big-4 yaitu sebanyak 128 perusahaan atau 61,2\% sedangkan KAP big-4 hanya digunakan oleh 81 perusahaan atau sekitar 38,8\%. Berdasarkan informasi data tersebut maka dapat disimpulkan bahwa perusahaan sektor barang konsumsi yang 
digunakan sebagai sampel penelitian lebih banyak yang tidak menggunakan KAP yang berafiliasi dengan KAP big-4.

Sementara itu variabel kontrol dalam penelitian ini yaitu profitabilitas (PROFIT) memiliki nilai minimum sebesar $-26,037 \%$ dan nilai maksimum $92,100 \%$ serta rata-rata $7,893 \%$. Nilai negatif tersebut mengindikasikan bahwa terdapat perusahaan yang mengalami kerugian (loss). Tetapi rata-rata perusahaan yang digunakan sebagai sampel penelitian menunjukkan nilai positif yang berarti bahwa perusahaan masih mengalami keuntungan (profit). Untuk variabel ukuran perusahaan (SIZE) yang diukur menggunakan logaritma natural dari total aset, didapatkan nilai minimum sebesar 25,332 sedangkan nilai maksimum 32,201 serta rata-rata senilai 28,409.

\section{Uji Asumsi Klasik}

Sebelum melakukan pengujian terhadap hipotesis, maka terlebih dahulu diperlukan uji asumsi klasik untuk memperoleh model regresi penelitian yang baik dan tepat (Ghozali, 2015). Hasil uji normalitas yang dilakukan dengan menggunakan uji Kolmogornov-Smirnov menunjukkan bahwa residu (eror) dari model regresi berdistribusi tidak normal, dikarenakan nilai asymp. sig yang dihasilkan sebesar 0,000 atau lebih kecil dari $\alpha(5 \%)$. Oleh sebab itu dikarenakan hasil yang tidak berdistribusi dengan normal maka menurut Gujarati (2007) untuk asumsi uji normalitas dapat dilakukan dengan menggunakan Central Limit Theorem.

Apabila jumlah data atau sampel yang digunakan lebih dari $\geq 30$, maka sampel tersebut dianggap berdistribusi normal. Lalu untuk hasil uji multikolinearitas pada tabel coefficients menunjukkan nilai tolerance $>0,10$ yaitu berada pada rentang nilai 0,675 sampai 0,954, atau nilai VIF < 10 yaitu berada pada rentang nilai 1,048 sampai 1,481 hal tersebut berarti bahwa model regresi yang digunakan tidak memiliki gejala multikolinearitas. Selain itu model regresi dalam penelitian ini juga tidak mengalami gejala heterokedastisitas, yang ditunjukkan dengan nilai signifikan pada uji Glejser bernilai > 0,05. Sedangkan untuk uji autokorelasi yang dilakukan dengan menggunakan uji Durbin-Watson menunjukkan nilai sebesar 2,003 yang berada di daerah yang tidak terjadi autokorelasi. Dengan demikian telah terpenuhi semua uji prasyarat asumsi klasik, maka dari itu dapat disimpulkan bahwa model regresi yang digunakan sudah tepat.

\section{Uji Hipotesis}

Tabel 3 menunjukkan hasil pengujian koefisien determinasi $\left(\mathrm{R}^{2}\right)$ yang menunjukkan seberapa besar pengaruh yang diberikan oleh variabel bebas terhadap variabel terikat.

Tabel 3. Hasil Pengujian Koefisien Determinasi

\begin{tabular}{|c|c|c|c|c|c|}
\hline Model & $\mathrm{R}$ & R Square & Adjusted R Square & $\begin{array}{l}\text { Std. Error of } \\
\text { the Estimate }\end{array}$ & $\begin{array}{l}\text { Durbin } \\
\text { Watson }\end{array}$ \\
\hline 1 & 0,525 & 0,275 & 0,254 & 0,12241 & 2,003 \\
\hline
\end{tabular}

Berdasarkan hasil pengujian koefisien determinasi, $R$ Square menunjukkan nilai 0,275 atau 27,5\%. Hal ini berarti bahwa sebesar 27,5\% manajemen laba real pada perusahaan publik sektor barang konsumsi tahun 2014-2018 secara simultan dipengaruhi oleh komposisi dewan komisaris independen, CEO tenure, ukuran kantor akuntan publik, profitabilitas, dan ukuran perusahaan sedangkan $72,5 \%$ dipengaruhi oleh faktor lain di luar penelitian ini.

Tabel 4 menunjukkan hasil pengujian koefisien determinasi $\left(\mathrm{R}^{2}\right)$ untuk faktor internal sedangkan Tabel 5 menunjukkan hasil pengujian $\mathrm{R}^{2}$ untuk faktor eksternal.

Tabel 4. Hasil Pengujian Koefisien Determinasi Faktor Internal

\begin{tabular}{|c|c|c|c|c|}
\hline Model & $\mathrm{R}$ & R Square & Adjusted R Square & $\begin{array}{l}\text { Std. Error of the } \\
\text { Estimate }\end{array}$ \\
\hline 1 & 0,590 & 0,348 & 0,332 & 0,123905 \\
\hline
\end{tabular}

Berdasarkan hasil pengujian koefisien determinasi untuk faktor internal, $R$ Square menunjukkan nilai 0,348 atau 34,8\%. Hal ini berarti bahwa faktor internal yang terdiri dari CEO tenure dan komposisi 
dewan komisaris independen, serta variabel kontrol profitabilitas dan ukuran perusahaan mempengaruhi manajemen laba real sebesar $34,8 \%$.

Tabel 5. Hasil Pengujian Koefisien Determinasi Faktor Eksternal

\begin{tabular}{lllll}
\hline Model & $\mathrm{R}$ & R Square & Adjusted R Square & $\begin{array}{l}\text { Std. Error of the } \\
\text { Estimate }\end{array}$ \\
\hline 1 & 0,573 & 0,328 & 0,318 & 0,125214 \\
\hline \multicolumn{4}{r}{} & \multicolumn{3}{r}{ Sumber: Data sekunder yang diolah tahun 2020. }
\end{tabular}

Berdasarkan hasil pengujian koefisien determinasi untuk faktor eksternal, $R$ Square menunjukkan nilai 0,328 atau $32,8 \%$. Hal ini berarti bahwa faktor eksternal yang terdiri dari ukuran kantor akuntan publik serta variabel kontrol profitabilitas dan ukuran perusahaan mempengaruhi manajemen laba real sebesar $32,8 \%$.

Tabel 6 menunjukkan hasil pengujian uji $\mathrm{F}$ untuk mengetahui apakah terdapat pengaruh secara simultan dari variabel bebas terhadap variabel terikat.

Tabel 6. Hasil Uji F

\begin{tabular}{llccccc}
\hline Model & & Sum of Squares & $\mathrm{df}$ & Mean Square & $\mathrm{F}$ & Sig \\
\hline 1 & Regression & 1,665 & 6 & 0,278 & 17,993 & 0,000 \\
& Residual & 3,116 & 202 & 0,15 & & \\
& Total & 4,782 & 208 & & & \\
\hline & \multicolumn{5}{c}{ Sumber: Data sekunder yang diolah tahun 2020. }
\end{tabular}

Berdasarkan hasil pengujian uji F menunjukkan bahwa komposisi dewan komisaris independen, CEO tenure, ukuran kantor akuntan publik, profitabilitas, dan ukuran perusahaan secara simultan berpengaruh terhadap manajemen laba real karena nilai signifikan $<0,05$.

Tabel 7. Hasil Analisis Regresi Berganda

\begin{tabular}{|c|c|c|c|c|c|c|}
\hline \multirow{2}{*}{$\begin{array}{l}\text { Mo } \\
\text { del }\end{array}$} & & \multicolumn{2}{|c|}{ Unstandardized Coefficients } & \multirow{2}{*}{$\begin{array}{c}\text { Standardized } \\
\text { Coefficients }\end{array}$} & \multirow{2}{*}{$\mathrm{t}$} & \multirow{2}{*}{ Sig } \\
\hline & & B & Std. Error & & & \\
\hline \multirow[t]{7}{*}{1} & (Constant) & 0,337 & 0,176 & & 1,914 & 0,057 \\
\hline & CEO Awal & $-0,009$ & 0,021 & $-0,024$ & $-0,415$ & 0,679 \\
\hline & CEO Akhir & $-0,027$ & 0,022 & $-0,073$ & $-1,248$ & 0,213 \\
\hline & $\begin{array}{l}\text { Komposisi Dewan Komisaris } \\
\text { Independen }\end{array}$ & 0,155 & 0,073 & 0,130 & 2,136 & $0,034^{*}$ \\
\hline & Ukuran KAP & 0,003 & 0,021 & 0,010 & 0,148 & 0,882 \\
\hline & Profitabilitas & 0,007 & 0,001 & 0,564 & 8,650 & $0,000^{*}$ \\
\hline & Ukuran Perusahaan & $-0,016$ & 0,006 & $-0,162$ & $-2,495$ & $0,013^{*}$ \\
\hline
\end{tabular}

Sumber: Data sekunder yang diolah tahun 2020.

Berdasarkan Tabel 7 di atas, variabel CEO Awal menunjukkan nilai signifikansi 0,679 atau lebih besar dari $\alpha(5 \%)$ yang berarti bahwa variabel ini tidak berpengaruh terhadap praktik manajemen laba real. Begitu juga dengan variabel CEO Akhir menunjukkan nilai signifikansi 0,213. Kemudian, variabel komposisi dewan komisaris independen menunjukkan nilai signifikansi 0,034 dengan nilai beta bernilai positif, hal ini berarti bahwa komposisi dewan komisaris independen berpengaruh positif terhadap manajemen laba real. Kemudian variabel ukuran KAP menunjukkan nilai signifikansi sebesar 0,882 yang berarti bahwa ukuran KAP tidak berpengaruh terhadap praktik manajemen laba real yang dilakukan oleh perusahaan.

Untuk kedua variabel kontrol yaitu profitabilitas dan ukuran perusahaan menunjukkan hasil yang berpengaruh terhadap manajemen laba real. Profitabilitas memiliki nilai signifikansi 0,000 dan beta yang positif hal ini berarti bahwa profitabilitas berpengaruh positif terhadap manajemen laba real. Sedangkan variabel ukuran perusahaan berpengaruh negatif terhadap manajemen laba real dengan nilai signifikansi 0,013 dengan beta bernilai negatif. 
Penelitian ini menggunakan pengujian tambahan untuk memperoleh alternatif hasil yang lebih tepat. Pengujian tambahan digunakan untuk mengetahui apakah terdapat indikasi mengenai pengaruh CEO terhadap manajemen laba. Pengujian ini dilakukan dengan menggunakan uji wilcoxon signed rank test untuk mengetahui apakah terdapat perbedaan rata-rata manajemen laba diawal dan akhir masa kerja CEO.

Tabel 8. Uji Wilcoxon Signed Rank

\begin{tabular}{lr}
\hline & Test Statistics \\
\hline Z & $-0,604$ \\
Asymp. Sig. (2-tailed) & 0,546 \\
\hline
\end{tabular}

Sumber: Data sekunder yang diolah tahun 2020.

Berdasarkan uji wilcoxon pada Tabel 8, tingkat signifikansi berada pada nilai 0,546 atau lebih besar dari $\alpha(0,05)$. Hal ini menunjukkan bahwa tidak terdapat perbedaan rata-rata antara manajemen laba bagi CEO yang berada diawal dan akhir masa kerja, berarti bahwa tidak terdapat pengaruh antara CEO tenure dengan manajemen laba real.

Berdasarkan hasil pengujian regresi pada Tabel 7, CEO awal dan CEO akhir tidak berpengaruh terhadap manajemen laba real. Untuk variabel CEO awal memiliki nilai signifikansi 0,679> $\alpha(0,05)$ sedangkan CEO akhir sebesar 0,213 > $\alpha(0,05)$. Begitu juga dengan hasil pengujian tambahan yang dilakukan dengan menggunakan uji wilcoxon signed rank pada tabel 8 menghasilkan kesimpulan yang sama. Penelitian ini belum dapat membuktikan bahwa terdapat pengaruh antara CEO tenure baik diawal maupun akhir masa kerja terhadap tindakan manajemen laba real. Pergantian CEO rutin memiliki salah satu ciri yaitu CEO yang telah selesai menjabat akan ditempatkan menjadi anggota dewan komisaris, maka dari itu CEO yang baru menjabat akan mendapat pengawasan oleh CEO lama sehingga semakin mempersempit kesempatan untuk melakukan manajemen laba (Adiasih \& Kusuma, 2011). Selain itu perusahaan sampel yang digunakan memiliki tenure yang sangat bervariasi yakni terdapat CEO yang menjabat hanya setiap dua tahun dan ada juga yang menjabat 5 tahun. Hal ini kemungkinan juga disebabkan oleh karena periode penelitian yang tidak terlalu panjang sehingga tidak mempunyai gambaran yang cukup komprehensif atas pergantian CEO yang ada dan CEO bisa saja melakukan manajemen laba dengan cara yang lain misalnya melalui discretionary accrual, abnormal production costs, atau abnormal Discretionary expenses seperti penelitian yang dilakukan oleh Vernando \& Rakhman (2018), Dewi \& Rasmini (2018), dan Yasa \& Novialy (2012)

Sedangkan variabel komposisi dewan komisaris independen menunjukkan hasil yang berpengaruh terhadap manajemen laba real, dengan arah positif dan nilai signifikansi sebesar 0,034. Hal ini mengindikasikan bahwa adanya dewan komisaris independen dalam sebuah perusahaan tidak digunakan untuk memperkuat good corporate governance perusahaan tetapi hanya dimaksudkan guna memenuhi regulasi yang ada. Peran penting di dalam perusahaan masih dalam kendali pendiri dan pemilik saham mayoritas perusahaan sehingga fungsi pengawasan dewan komisaris independen pun menjadi tidak begitu signifikan. Hal ini sejalan dengan penelitian yang dilakukan oleh Dewi \& Khoiruddin (2016) bahwa komposisi dewan komisaris independen berpengaruh positif terhadap manajemen laba. Hasil tersebut juga dibuktikan dengan data pada perusahaan sampel PT Siantar Top Tbk (STTP) pada tahun 2017, walaupun tidak memiliki dewan komisaris independen PT Siantar Top Tbk memiliki nilai abnormal CFO yang bernilai positif yaitu 0,016 yang berarti bahwa perusahaan tidak terindikasi melakukan manajemen laba real.

Sedangkan PT Tempo Scan Pacific Tbk (TSPC) pada tahun 2018 memiliki dewan komisaris independen berjumlah tiga orang dari lima orang secara keseluruhan, namun justru nilai abnormal CFOnya sebesar -0,070 yang berarti bahwa manajemen laba real dalam perusahaan justru lebih tinggi jika dibandingkan dengan STTP. Namun penelitian ini tidak sejalan dengan yang dilakukan Fatmawati (2018) dan Nabila \& Daljono (2013) yang menyatakan bahwa komposisi dewan komisaris independen berpengaruh negatif terhadap manajemen laba hal ini disebabkan bahwa perusahaan tidak melakukan manajemen laba apabila terdapat banyak dewan komisaris independen yang melakukan pengawasan.

Faktor eksternal dalam penelitian ini terdiri dari ukuran KAP. Berdasarkan hasil pengujian pada Tabel 7 menunjukkan bahwa tidak terdapat pengaruh signifikan antara ukuran KAP terhadap manajemen laba real, yang ditunjukkan dengan nilai signifikansi sebesar 0,882 $>\alpha(0,05)$. Hal ini berarti bahwa tidak terdapat perbedaan antara KAP afiliasi big-4 dan non big-4 dalam mendeteksi praktik manajemen laba real. Semua KAP big-4 maupun non big-4 harus memberikan jasa secara profesional kepada setiap kliennya, oleh karena itu kualitas audit yang dihasilkannya juga harus setara. Bahkan KAP big-4 sekalipun 
apabila memiliki hubungan yang tidak independen dengan klien maka tindakan manajemen laba dengan cara apapun tidak akan terdeteksi (Astuti \& Pangestu, 2019).

Selain itu manajemen laba real juga lebih sulit untuk terdeteksi baik oleh KAP big-4 maupun non big-4 dikarenakan metode pelaksanaannya yang sama seperti aktivitas normal operasi perusahaan. Hal ini juga dibuktikan dengan perusahaan Multi Bintang Indonesia Tbk pada tahun 2017 dengan menggunakan KAP afiliasi big-4 yaitu Deloitte memiliki nilai abnormal CFO sebesar 0,462 yang berarti perusahaan tidak terindikasi melakukan manajemen laba real sedangkan perusahaan Merck Sharp Dohme Pharma Tbk pada tahun 2014 juga menggunakan KAP afiliasi big-4 yaitu Pricewaterhouse Coopers (PWC) namun memiliki nilai abnormal CFO sebesar -0,563 yang berarti perusahaan terindikasi melakukan manajemen laba real. Penelitian ini sesuai dengan penelitian yang dilakukan oleh Alhadab \& Clacher (2018), Khanh \& Khuong (2018), dan Safriliana \& Rahami (2019) yang menyatakan bahwa tidak terdapat hubungan antara ukuran KAP dengan manajemen laba real, akan tetapi tidak sejalan dengan yang dilakukan oleh Inaam et al., (2012) dan Puspitasari \& Nugrahanti (2016) yang menyatakan bahwa ukuran KAP berpengaruh positif terhadap manajemen laba real, serta Nihlati \& Meiranto (2014) yang menyatakan ukuran KAP berpengaruh negatif terhadap manajemen laba real.

Berdasarkan Tabel 7, salah satu variabel kontrol yaitu profitabilitas memiliki pengaruh positif terhadap manajemen laba real, dengan nilai signifikansi $0,000<\alpha(0,05)$. Investor cenderung menyukai laba yang stabil pada sebuah perusahaan, apabila perusahaan menghasilkan profit yang tinggi maka manajer akan berfikir untuk melakukan manajemen laba agar laba yang dihasilkan lebih stabil. Hal ini juga dapat berkaitan dengan ketakutan seorang manajer apabila ditahun mendatang tidak dapat mencapai target laba yang ditetapkan oleh pemegang saham, dan juga berkaitan dengan pembayaran pajak karena dengan laba yang tinggi pajak yang harus dibayarkan oleh perusahaan juga tinggi. Penelitian ini sesuai dengan yang dilakukan oleh Astari \& Suryanawa (2017), Oktoriza (2018), serta Ricardo \& Faisal (2015) yang menyatakan bahwa profitabilitas berpengaruh positif terhadap manajemen laba real.

Untuk variabel kontrol kedua yaitu ukuran perusahaan juga terbukti berpengaruh negatif terhadap manajemen laba real dengan nilai signifikansi 0,013. Hal ini disebabkan karena perusahaan dengan ukuran besar yang dihitung dengan menggunakan logaritma natural of total asset, dianggap telah memiliki pengendalian internal yang kuat dan memadai sehingga dapat mengurangi adanya praktik manajemen laba di dalam perusahaan (Bassiouny, 2016). Perusahaan besar juga lebih dikenal dan diperhatikan oleh masyarakat secara luas, segala bentuk informasi keuangan yang tidak akurat atau bahkan menyesatkan bagi stakeholder akan mempengaruhi kepercayaan pada perusahaan tersebut. Oleh karena itu perusahaan cenderung bertindak hati-hati dalam menyajikan dan mengungkapkan laporan keuangannya. Penelitian ini sejalan dengan yang dilakukan oleh Deviyanti \& Sudana (2018) serta Vernando \& Rakhman (2018) akan tetapi tidak sesuai dengan penelitian Octavia (2017) dan Oktoriza (2018) yang menyatakan bahwa ukuran perusahaan berpengaruh positif terhadap manajemen laba real.

\section{Simpulan dan saran}

Berdasarkan hasil pengujian serta pembahasan yang telah dilakukan, penelitian ini menghasilkan kesimpulan bahwa CEO tenure dan ukuran KAP tidak berpengaruh terhadap manajemen laba real. Untuk variabel komposisi dewan komisaris independen terbukti berpengaruh positif terhadap manajemen laba real. Sedangkan untuk kedua variabel kontrol yang terdiri dari profitabilitas berpengaruh positif serta ukuran perusahaan berpengaruh negatif terhadap manajemen laba real. Hasil pengujian koefisien determinasi $\left(\mathrm{R}^{2}\right)$ untuk masing-masing faktor menunjukkan bahwa manajemen laba real lebih dipengaruhi oleh faktor internal yaitu sebesar $34,8 \%$, faktor eksternal juga memberikan pengaruh yang tidak terpaut jauh dengan faktor internal yaitu 32,8\%.

Penelitian ini memiliki beberapa keterbatasan seperti variabel CEO tenure diukur menggunakan variabel dummy dengan asumsi hanya pada pergantian rutin dalam masa jabatan 5 tahun, sehingga penelitian selanjutnya diharapkan dapat menambah indikator lain untuk mengukur CEO tenure yaitu seperti pergantian CEO non rutin yang disebabkan oleh pemecatan. Penelitian mendatang juga dapat menambah indikator lain untuk mengukur manajemen laba selain menggunakan manajemen laba real dengan proksi abnormal CFO. Penelitian ini diharapkan dapat menjadi bahan pertimbangan bagi calon investor agar mengetahui bagaimana manajemen laba terjadi dalam perusahaan.

\section{Daftar Rujukan}

Adiasih, P., \& Kusuma, I. W. (2011). Manajemen Laba Pada Saat Pergantian CEO (Dirut) Di Indonesia. Jurnal Akuntansi Dan Keuangan, 13(2), 67-79.

Alhadab, M., \& Clacher, I. (2018). The impact of Audit Quality on Real and Accrual Earnings Management 
Around IPOs. British Accounting Review, 50(4), 442-461. https://doi.org/10.1016/j.bar.2017.12.003

Arief, I. A. (2019). Astaga! Tiga Pilar Disebut Gelembungkan Keuangan Rp 4 T. Retrieved January 16, 2020, from https://www.cnbcindonesia.com/market/20190327082221-17-63104/astaga-tiga-pilardisebut-gelembungkan-keuangan-rp-4-t

Astari, A. A. M. R., \& Suryanawa, I. K. (2017). Faktor-faktor yang Mempengaruhi Manajemen Laba. E-Jurnal Akuntansi Universitas Udayana, 20(1), 290-319.

Astuti, C. D., \& Pangestu, N. (2019). Kualitas Audit, Karakteristik Perusahaan dan Manajemen Laba Riil. Jurnal Media Riset Akuntansi, Auditing \& Informasi, 19(2), 191-208.

Bassiouny, S. W. (2016). The Impact of Firm Characteristics on Earnings Management : an empirical study on the listed firms in Egypt. Journal of Business and Retail Management Research, 10(3), 34-45.

Braam, G., Nandy, M., Weitzel, U., \& Lodh, S. (2015). Accrual-Based and Real Earnings Management and Political Connections. The International Journal of Accounting, 50(2), 111-141. https://doi.org/https://doi.org/10.1016/j.intacc.2013.10.009

Deviyanti, N. W. T., \& Sudana, I. P. (2018). Pengaruh Bonus, Ukuran Perusahaan, dan Leverage pada Manajemen Laba. E-Jurnal Akuntansi Universitas Udayana, 23(2), 1415-1441.

Dewi, E. R., \& Khoiruddin, M. (2016). Pengaruh Good Corporate Governance Terhadap Manajemen Laba pada Perusahaan yang Masuk Dalam JII (Jakarta Islamic Index) Tahun 2012-2013. Management Analysis Journal, 5(3), 156-166.

Dewi, N. M. A. K., \& Rasmini, N. K. (2018). Perbedaan Earnings Management pada Pergantian Chief Executive Officer pada Perusahaan Manufaktur yang Terdaftar di BEI. E-Jurnal Akuntansi Universitas Udayana, 23(2), 1442-1469. https://doi.org/https://doi.org/10.24843/EJA.2018.v23.i02.p24

Fatmawati, Y. (2018). Pengaruh Mekanisme Good Corporate Governance Terhadap Manajemen Laba. Jurnal Akuntansi, 6(1), 1-26.

Ghozali, I. (2015). Ekonometrika: Teori, Konsep dan Aplikasi dengan IBM SPSS 22. Semarang: Badan Penerbit Universitas Diponegoro.

Gujarati, D. N. (2007). Dasar-Dasar Ekonometrika (3rd ed.). Jakarta: Erlangga.

Hanna, \& Haryanto, M. (2016). Agresivitas Pelaporan Keuangan, Agresivitas Pajak, Tata Kelola Perusahaan dan Kepemilikan Keluarga. Jurnal Akuntansi, 20(3), 407-419.

Inaam, Z., Khmoussi, H., \& Fatma, Z. (2012). Audit Quality and Earnings Management in the Tunisian Context. International Journal of Accounting and Financial Reporting, 2(2), 17-33. https://doi.org/10.5296/ijafr.v2i2.2065

Khanh, H. T. M., \& Khuong, N. V. (2018). Audit Quality, Firm Characteristics and Real Earnings Management: The Case of Listed Vietnamese Firms. International Journal of Economics and Financial Issues, 8(4), 243-249. Retrieved from http:www.econjournals.com

Kristiani, K. E., Sulindawati, N. L. G., \& Herawati, N. T. (2014). Pengaruh Mekanisme Corporate Governance dan Ukuran Perusahaan terhadap Manajemen Laba pada Perusahaan Manufaktur yang Terdaftar di BEI. E-Journal S1 Akuntansi Universitas Pendidikan Ganesha, 1(1).

Marpaung, C. O., \& Latrini, N. M. Y. (2014). Pengaruh Dewan Komisaris Independen, Komite Audit, Kualitas Audit dan Kepemilikan Manajerial pada Perataan Laba. E-Jurnal Akuntansi Universitas Udayana, 7(2), 279-289.

Muniroh, H. (2016). President Director Tenure And Earnings Management. Jurnal Akuntansi Indonesia, 5(2), 149-162.

Nabila, A., \& Daljono. (2013). Pengaruh Proporsi Dewan Komisaris Independen, Komite Audit, dan Reputasi Auditor Terhadap Manajemen Laba. Diponegoro Journal Of Accounting, 2(1), 1-10.

Nihlati, H., \& Meiranto, W. (2014). Analisis Pengaruh Kualitas Audit Terhadap Earnings Management. Diponegoro Journal Of Accounting, 3(3), 1-10. 
Octavia, E. (2017). Implikasi Corporate Governance dan Ukuran Perusahaan pada Manajemen Laba. Jurnal $\begin{array}{lll}\text { Akuntansi Multiparadigma, } & 8(1), & 126-135 .\end{array}$ https://doi.org/http://dx.doi.org/10.18202/jamal.2017.04.7044

Oktoriza, L. A. (2018). Pengaruh Leverage, Profitabilitas, Ukuran Perusahaan, Nilai Perusahaan, Aktivitas Komite Audit dan Kepemilikan Manajerial Terhadao Praktik Perataan Laba. Journal of Management \& Business, 1(2), 188-203.

Puspitasari, A., \& Nugrahanti, Y. W. (2016). Pengaruh Hubungan Politik , Ukuran Kap , dan Audit Tenure Terhadap Manajemen Laba Riil. Jurnal Akuntansi Dan Keuangan, 18(1), 27-43. https://doi.org/10.9744/jak.18.1.27-43

Ratmono, D. (2010). Manajemen Laba Rill dan Berbasis Akrual: Dapatkah Auditor yang Berkualitas Mendeteksinya? In Simposium Nasional Akuntansi XIII. Purwokerto.

Ricardo, D. M., \& Faisal. (2015). Pengaruh Pengungkapan Corporate Social Responsibility terhadap Praktik Manajemen Laba. Diponegoro Journal Of Accounting, 4(3), 1-9.

Safriliana, R., \& Rahami, W. (2019). Pengaruh Ukuran KAP, Spesialisasi Industri Auditor, dan Audit Capacity Stress terhadap Manajemen Laba Melalui Manipulasi Aktivitas Riil. Jurnal Akuntransi Aktual, 6(2), 280-289.

Susanto, I. R., \& Majid, J. (2017). Faktor-Faktor yang Mempengaruhi Manajemen Laba pada Perusahaan Manufaktur di BEI. Jurnal Ilmiah Akuntansi Peradaban, 3(2), 65-83.

Vernando, A., \& Rakhman, F. (2018). Masa Kerja CEO dan Manajemen Laba (CEO Tenure dan Earnings Management). Jurnal Akuntansi Dan Keuangan Indonesia, 15(2), 201-215.

Yasa, G. W., \& Novialy, Y. (2012). Indikasi Manajemen Laba Oleh Chief Executive Officer (CEO) Baru Pada Perusahaan-perusahaan yang Terdaftar di Pasar Modal Indonesia. Jurnal Ilmiah Akuntansi Dan Binis, $7(1), 1-24$. 